\title{
Laparoscopic cholecystectomy in patients with situs inversus totalis: case report and review of reported surgical techniques
}

\author{
Talha Sarigoz,, ${ }^{1}$ Tamer Ertan,, ${ }^{2}$ Omer Topuz, ${ }^{2}$ Yusuf Sevim ${ }^{3}$ \\ 'Department of General Surgery, Sason State Hospital, Batman, Turkey \\ ${ }^{2}$ Department of General Surgery, Kayseri Training and Research Hospital, Kayseri, Turkey \\ ${ }^{3}$ Department of General Surgery, Numune Training and Research Hospital, Ankara, Turkey
}

\section{Dear Editor,}

Cholecystectomy is the most affected procedure by the appearance of laparoscopy. It is also true that no other practice has been more contributory in laparoscopic era than laparoscopic cholecystectomy has. ${ }^{[1]}$ Nowadays, it is the most commonly performed abdominal surgical procedure and it is the gold standard treatment for the removal of gallbladder ${ }^{[2]}$ But, in rare cases such as situs inversus totalis (SIT), the management pose difficulty both in diagnosis and treatment. In this letter, we present a patient with SIT to discuss differences in diagnostic approach and laparoscopic technique reported in the literature.

A 40-year-old female patient was admitted to surgery clinic with recurrent crampy epigastric pain and postprandial vomiting of 3 months duration. In the patient's history, it was also learned that the patient was diagnosed with SIT 15 years ago. Abdominal examination was unremarkable. Fundus gas and cardiac shadow were right-sided on the chest X-ray. Hemogram and biochemistry panel was normal. Computed tomography scan was performed to confirm the diagnosis and it showed reversed positioned liver, stomach and spleen (Figure 1, 2). In the abdominal ultrasonography, gallbladder stone was noted reaching 1 $\mathrm{cm}$ in size at the neck of gallbladder and width of the common bile duct was within normal range. Upon symptomatic complaints and radiological evaluation, the patient was planned for elective surgery and hospitalized.

Preoperatively, mirror image setup was established in the operating theatre. The monitor was placed over the left shoulder of the patient. Left-handed surgeon and first assistant stood on the right side and second assistant on the left side of the patient. Laparoscopic cholecystectomy was performed under elective setting by using mirror-image 4 port configuration with a $12-\mathrm{mm}$ supra-umbilical camera port, a 10-mm epigastric port for dissection and two 5-mm ports below the subcostal margin, one in the mid-clavicular line for grasping infundibulum and one in the anterior axillary line for retracting fundus. Abdominal organs were observed in the mirror image position during laparoscopic exploration. Second assistant retracted the fundus, the surgeon dissected Calot's triangle, clipped cystic artery, cystic duct and removed gallbladder from liver bed by using epigastric port. Total operation length was 70 minutes. At post-operative $6^{\text {th }}$ hour, clear diet was initiated and at post-operative $2^{\text {nd }}$ day, the patient was discharged without any complications. 


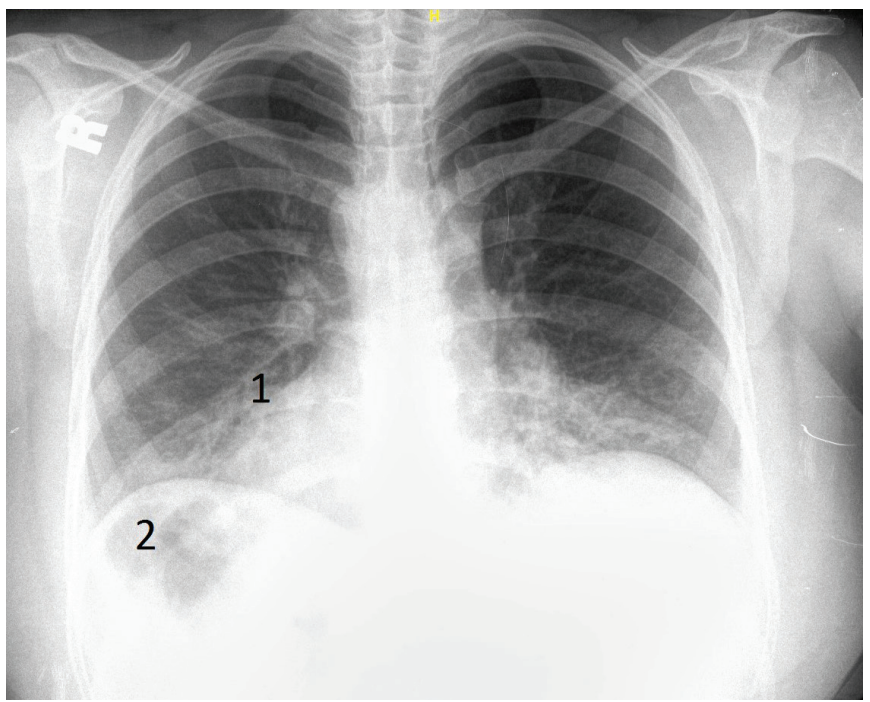

Figure 1. Posteroanterior (PA) chest X-ray showing dextrocardia. 1: Ventricular shadow, 2: Fundus gas.

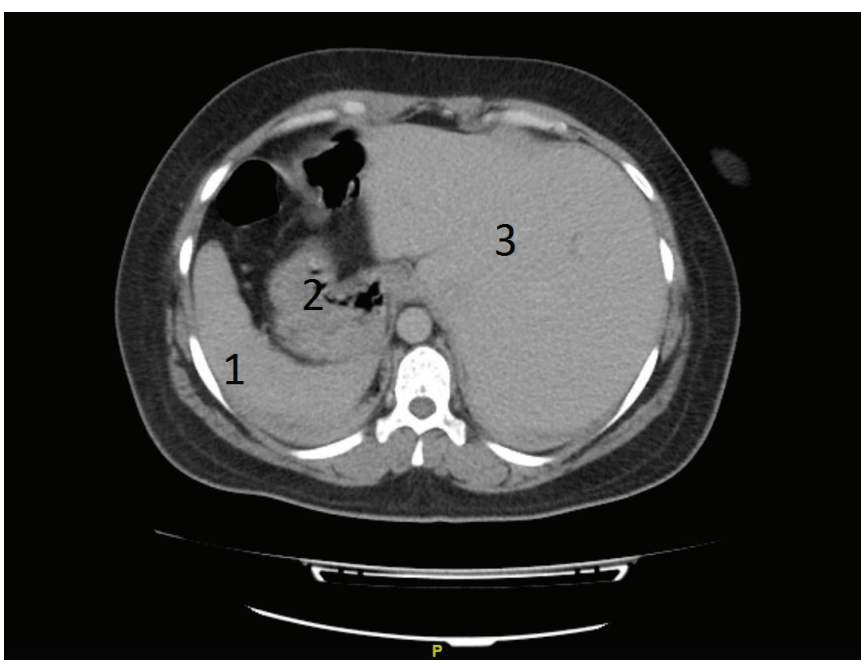

Figure 2. Coronal plane abdominal tomography scan showing reversed positioning of abdominal organs. 1: Spleen, 2: Stomach, 3: Liver.

Since the first report describing SIT by Girolamo Fabrizio around 1600 , various cases were published without knowing exact cause. Today, it is commonly known that situs inversus is a rare congenital anomaly with autosomal recessive inheritance. ${ }^{[3]}$ It is characterized by inver- sion of the major visceral organs. But, related to degree of rotation, it can be total or partial. This difference may cause other congenital anomalies such as biliary atresia, congenital heart disease and renal dysplasia. Also, vascular and biliary structure anomalies may be present. But it is not a factor that increase risk of gallstone disease. Incidence of cholelithiasis is thought to be same as orthotopic population (Table 1). ${ }^{[4]}$

Cholecystectomy is the most common surgical procedure reported in patients with SIT. ${ }^{[5]}$ First example of this procedure was reported in 1957 by Houle and Viger and with the advent of laparoscopy, Campos and Sipes performed first laparoscopic cholecystectomy in a patient with SIT in 1991. $[6,7]$ Thenceforth, various cases of laparoscopic procedures have been reported. Common point shared in these reports is that due to reversed anatomy, dissection poses difficulty for right-handed surgeons. So that most of the published reports have described different methods for better orientation. It is also clear that left-handed surgeons have the privilege of better adapting to reversed anatomy (Table 2).

However, not only the dissection but also the diagnosis of intraabdominal pathologies can be challenging in these patients if the diagnosis has not been made previously. Left upper quadrant pain as a result of left-sided gallbladder is the most common presentation of acute cholecystitis but in $\% 10$ of the cases, right sided pain was reported. ${ }^{\text {[4] }}$ Posteroanterior chest X-ray is a cost-effective modality to diagnose SIT. Right-sided fundus gas and left ventricular shadow on chest X-ray are diagnostic. To confirm the diagnosis, computed tomography (CT) scan can be performed. It is also a valuable modality to see if other biliary or vascular anomalies are present.

In conclusion, laparoscopy cholecystectomy seems feasible and safe in patients with SIT in the light of the literature. As in all procedures, careful planning and appropriate operation theatre set up including proper modifications in anesthetic management must be established before the surgery. ${ }^{[8]}$ There isn't enough evidence to

Table 1. Results of literature search performed on July 13, 2017

\begin{tabular}{llcc} 
Database & Search strategy & \multicolumn{2}{c}{ Results } \\
\cline { 3 - 3 } Medline (via Pubmed) & $\begin{array}{l}\text { Found } \\
\text { "situs inversus"[MeSH] or "situs" AND "inversus" or } \\
\text { "situs inversus" and "cholecystectomy"[MeSH] or } \\
\text { "cholecystectomy" }\end{array}$ & 131 & 73 \\
\hline
\end{tabular}


Table 2. Literature review on the technical aspects of laparoscopic cholecystectomy in situs inversus totalis

\begin{tabular}{|c|c|c|c|c|c|c|c|}
\hline & $\begin{array}{c}\text { Surgeon } \\
\text { dominant } \\
\text { hand }\end{array}$ & $\begin{array}{l}\text { Patient } \\
\text { position }\end{array}$ & Camera port & Dissecting port & $\begin{array}{c}\text { Retraction } \\
\text { Port } 1 \\
\text { (Infundibulum) }\end{array}$ & $\begin{array}{c}\text { Retraction port } 2 \\
\text { (Fundus) }\end{array}$ & $\begin{array}{c}\text { The mean } \\
\text { operating } \\
\text { time }\end{array}$ \\
\hline Patle et al. ${ }^{[9]}$ & Right & Lithotomy & Infraumblical & $\begin{array}{c}5 \mathrm{~mm} \text { left } \\
\text { midclavicular }\end{array}$ & $\begin{array}{c}10 \mathrm{~mm} \\
\text { epigastric }\end{array}$ & $\begin{array}{c}5 \mathrm{~mm} \text { left } \\
\text { anterior axillary }\end{array}$ & 65 mins \\
\hline Salama et al. ${ }^{[10]}$ & Right & Supine & Infraumbilical & $10 \mathrm{~mm}$ epigastric & $\begin{array}{c}5 \mathrm{~mm} \text { left } \\
\text { midclavicular }\end{array}$ & $\begin{array}{c}5 \mathrm{~mm} \text { left } \\
\text { anterior axillary }\end{array}$ & - \\
\hline Arya et al..$^{[11]}$ & Right & $\begin{array}{c}\text { Reverse } \\
\text { trendelenburg }\end{array}$ & Infraumbilical & $\begin{array}{l}10 \mathrm{~mm} \text { epigastric } \\
\text { left to midline }\end{array}$ & $\begin{array}{c}5 \mathrm{~mm} \text { left } \\
\text { midclavicular }\end{array}$ & $\begin{array}{c}5 \mathrm{~mm} \text { left } \\
\text { anterior axillary }\end{array}$ & 95 mins \\
\hline Ali et al. ${ }^{[12]}$ & Right & - & Infraumbilical & $\begin{array}{l}10 \mathrm{~mm} \text { left } \\
\text { midclavicular }\end{array}$ & $\begin{array}{l}5 \mathrm{~mm} \text { right } \\
\text { midclavicular }\end{array}$ & $\begin{array}{c}5 \mathrm{~mm} \text { left } \\
\text { anterior axillary }\end{array}$ & 70 mins \\
\hline RaghuveeR et al..$^{[13]}$ & Right & Lloyd-Davies & Infraumbilical & $10 \mathrm{~mm}$ epigastric & $\begin{array}{l}5 \mathrm{~mm} \text { right } \\
\text { midclavicular }\end{array}$ & $\begin{array}{c}5 \mathrm{~mm} \text { left } \\
\text { anterior axillary }\end{array}$ & 135 mins \\
\hline Ahmed et al..$^{[14]}$ & Right & - & Supraumbilical & $\begin{array}{c}5 \mathrm{~mm} \text { left } \\
\text { midclavicular }\end{array}$ & $\begin{array}{c}10 \mathrm{~mm} \text { left } \\
\text { paramedian } \\
5 \mathrm{~cm} \text { caudally } \\
\text { from xiphoid }\end{array}$ & $\begin{array}{c}5 \mathrm{~mm} \text { left } \\
\text { anterior axillary }\end{array}$ & 48 mins \\
\hline Fanshawe et al. ${ }^{[15]}$ & Right & Lloyd-Davies & $\begin{array}{l}10 \mathrm{~mm} \text { left } \\
\text { midclavicular }\end{array}$ & $\begin{array}{l}5 \mathrm{~mm} \text { left } \\
\text { subcostal }\end{array}$ & $\begin{array}{c}5 \text { mm supra- } \\
\text { umbilical }\end{array}$ & $5 \mathrm{~mm}$ subxiphoid & 60 mins \\
\hline Alam et al..$^{[16]}$ & Right & $\begin{array}{c}\text { Reverse } \\
\text { trendelenburg }\end{array}$ & Infraumbilical & $\begin{array}{c}10 \mathrm{~mm} \\
\text { subxiphoid }\end{array}$ & $\begin{array}{c}5 \mathrm{~mm} \text { left } \\
\text { midclavicular }\end{array}$ & $\begin{array}{c}5 \mathrm{~mm} \text { left } \\
\text { anterior axillary }\end{array}$ & 70 mins \\
\hline Alsabek et al. ${ }^{[17]}$ & Left & - & Infraumbilical & $\begin{array}{c}10 \mathrm{~mm} \\
\text { subxiphoid }\end{array}$ & $\begin{array}{c}5 \mathrm{~mm} \text { left } \\
\text { midclavicular }\end{array}$ & $\begin{array}{c}5 \mathrm{~mm} \text { left } \\
\text { anterior axillary }\end{array}$ & 60 mins \\
\hline
\end{tabular}

support higher rate of biliary or vascular injury or, conversion to an open surgery during laparoscopic cholecystectomy in patients with SIT but, utmost precaution should be taken in handling cases of SIT.

\section{References}

1. NIH Consensus conference. Gallstones and laparoscopic cholecystectomy. JAMA 1993;269:1018-24. [CrossRef]

2. Litwin DE, Cahan MA. Laparoscopic cholecystectomy. Surg Clin North Am 2008;88:1295-313. [CrossRef]

3. Kosaki K, Bassi MT, Kosaki R, Lewin M, Belmont J, Schauer G, et al. Characterization and mutation analysis of human LEFTY $A$ and LEFTY B, homologues of murine genes implicated in leftright axis development. Am J Hum Genet 1999;64:712-21.

4. Rao PG, Katariya RN, Sood S, Rao PL. Situs inversus totalis with calculus cholecystitis and mucinous cystadenomas of ovaries. J Postgrad Med 1977;23:89-90.

5. Okabayashi T, Shima Y, Sumiyoshi T, Kozuki A, Iwata J, Matsumoto $\mathrm{M}$, et al. General Abdominal Surgery in Patients with Situs Inversustotalis. Journal of Medical and Pharmaceutical Innovation 2015;2:1-8.

6. Houle MP, Viger LA. Cholecystectomy in a case of situs inversus totalis. J Maine Med Assoc 1957;48:8-11.

7. Campos L, Sipes E. Laparoscopic cholecystectomy in a 39-year-old female with situs inversus. J Laparoendosc Surg 1991;1:123-5. [CrossRef]

8. Eapen S, Ahluwalia C, Chopra V, Kiran S. Anaesthetic management for laparoscopic cholecystectomy in patient with situs inversus totalis. Indian J Anaesth 2015;59:57-8. [CrossRef]

9. Patle NM, Tantia O, Sasmal PK, Khanna S, Sen B. Laparoscopic cholecystectomy in situs inversus-our experience of 6 cases. Indian J Surg 2010;72:391-4. [CrossRef]

10. Salama IA, Abdullah MH, Houseni M. Laparoscopic cholecystectomy in situs inversus totalis: Feasibility and review of literature. Int J Surg Case Rep 2013;4:711-5. [CrossRef]

11. Arya SV, Das A, Singh S, Kalwaniya DS, Sharma A, Thukral BB. Technical difficulties and its remedies in laparoscopic cholecystectomy in situs inversus totalis: A rare case report. Int J Surg Case Rep 2013;4:727-30. [CrossRef]

12. Ali MS, Attash SM. Laparoscopic cholecystectomy in a patient with situs inversus totalis: case report with review of literature. BMJ Case Rep 2013;2013. pii: bcr2013201231.

13. Mn R, S MS, Bb SK. Laparoscopic cholecystectomy in situs inversus totalis. J Clin Diagn Res 2014;8:ND03-5.

14. Ahmed Z, Khan SA, Chhabra S, Yadav R, Kumar N, Vij V, et al. Our experience with surgery in situs inversus: Open peptic perforation repair and laparoscopic cholecystectomy in 1 patient and 3 patients respectively. Int J Surg Case Rep 2016;29:34-8.

15. Fanshawe AEE, Qurashi K. Laparoscopic cholecystectomy for gallstone pancreatitis in a patient with situs inversus totalis. J Surg Case Rep 2017;2017:rjx003.

16. Alam A, Santra A. Laparoscopic cholecystectomy in a case of situs inversus totalis: a review of technical challenges and adaptations. Ann Hepatobiliary Pancreat Surg 2017;21:84-7.

17. Alsabek MB, Arafat S, Aldirani A. A case report of laparoscopic cholecystectomy in situs inversus totalis: Technique and anatomical variation. Int J Surg Case Rep 2016;28:124-6. 